\title{
Relationship between Working Capital and Cash Lines Affects the Profit of Vietnam Securities Company \\ Trần Văn Hải
}

Hanoi University of Natural Resources and Environment

\begin{abstract}
Studying the relationship between working capital and cash flow affecting profitability of Vietnamese securities companies, through tobit model presented in the form of two-dimensional panel data: time dimension (from 2012 to 2019), the space dimension is the enterprise (48 securities companies), corresponding to 370 observations, using STATA 14 software to verify and estimate the tobit model. As a result, the relationship between working capital and cash flow (available cash flow) significantly affects the profitability of Vietnamese securities companies, Average collection period (ACP) has a negative relationship with ROE/ROA, while Average Payout Period (APP) has no significant effect on ROE/ROA. The implication is that securities companies can increase the profitability of the business by shortening the cash conversion cycle, shortening the receivable collection period, that is, for securities companies with positive cash flows, investment should be reduced. working capital to increase profitability.
\end{abstract}

\section{Introduction:}

Project No. 242/QD-TTg dated February 28, 2019 "restructuring the stock market and insurance market to 2020 and orientation to 2025" [2] has had remarkable results, number of securities companies in Vietnam tends to decrease in quantity and increase in quality, specifically in quantity, from 105 companies in 2009 until now according to statistics from HOSE and HNX (VNX). ), the number of securities companies still operating is only about 70 companies, the size and competitiveness of securities companies are significantly improved. Securities companies for many years have suffered long-term operating losses, leading to forced restructuring and self-restructuring through transformation and merger activities (typically, SHB Securities Company merged into Saigon Hanoi Securities Company, became Saigon Hanoi Securities Company; Vina Securities Company, after increasing capital and registering transactions on Upcom, in 2018 had a profit of over 5 billion dong). However, there is a matter of concern is the fact that there are many securities companies with large asset size, high income, large profit, and a lot of cash flow, but they just need to not balance revenue and expenditure. Money can still be difficult. Therefore, the balance of income and expenditure of cash flow in each period is the "real" balance, the balance affects the existence of the enterprise, and at the same time, this balance affects the profitability of the securities company.

\section{Content}

\subsection{Theoretical basis}

The term "Working capital" originates from the old American street vendors, who loaded up on horse-drawn carriages and peddled. Goods (Merchandises) are called "Working capital" or "working capital" because they are what peddlers actually sell, and are turned over to make a profit. Chariots and horses are fixed assets. Street vendors usually own carriages and horses (equity), but the goods are usually purchased on credit or with a bank loan, which they must pay to the bank after each sale to ensure that the borrower has ability to repay debt and prestige with the bank. The more trips a salesperson makes each year, the more working capital is being turned over and the more profitable it is. Therefore, people call working capital (working capital) as working capital because they rotate (usually used and rotated during the year). Understood in this way Working capital is the capital needed to turn finished materials and semi-finished products to collect cash, including cash, goods, receivables and other short-term assets that can be converted into cash in the short term. 
According to researcher Bui Thu Hien (2017), when referring to working capital, it means referring to the short-term assets of the business such as inventory, and short-term liabilities such as money owed to suppliers, and working capital play an important role in operational efficiency [1]. In other words, working capital is the entire amount of advance money that an enterprise spends to invest to form the necessary current assets to meet the requirements of production and business activities of the enterprise (Ha Quoc Thang , 2019). At the same time, according to Tran Van Hai (2020), the working capital structure includes: cash, receivables, inventory.

In fact, in the world, there are many studies on the content of working capital, especially considering the relationship between working capital, cash flow and business performance or profitability of enterprises, typically Lazaridis and partners (2006), argue that, there is statistical significance between profitability, measured through gross profit from operating activities and cash conversion cycle, managers can generate profits by correctly handling the cash conversion cycle and keeping the various components (accounts receivable, accounts payable, inventory) at optimal levels [9]. Ganesan (2007), Working Capital Management (VCM) is the management of short-term financial requirements of a company, including maintaining an optimal balance of working capital components, accounts receivable , inventory and accounts payable, and efficient use of cash for day-to-day operations [7]. The author's research results show that working capital is negatively related to profitability, but it does not significantly affect the profitability of the company. Less working capital requirements result in less financing needs and less capital expenditure and thus more cash available to shareholders. AIShattarat and partners (2010), managers can increase the profitability and operating cash flow of a business by shortening the cash conversion cycle, by shortening the receivables collection period. The results indicate that shortening the inventory conversion period and extending the payables deferral period will decrease the profitability and operating cash flow of firms instead of increasing them [6]. Vahid and partners (2012), there is a negative and significant relationship between the average collection period, daily inventory turnover, average payment period, net transaction cycle and operating efficiency, movements of companies listed on the Stock Exchange. There is no evidence to support the existence of a significant relationship between the cash conversion cycle and firm performance [11]. The author said that the case of increasing the collection period, payment period and net transactions will lead to a decrease in the company's profit, and managers can increase the profit of the company by rational, reducing collection, inventory turnover and payment period. Afrifa and partners (2016), there exists a concave relationship between the level of working capital (measured by the cash conversion cycle) and profitability, the optimal working capital level at which a company's profitability company is the maximum, below the optimal level, the profitability of the firm decreases [5]. Osama and partners (2020), net working capital (NWC) level has a non-linear effect on profitability when using (ROA) as a measure of return, while the results are insignificant when using (ROE) as a measure of profitability, while there is no interaction effect between (NWC), cash level. Kayani and partners (2020), working capital has a significant relationship with operating efficiency, cash conversion cycle (CCC) and inventory conversion period (ICP) exhibit a negative relationship. extreme for efficiency, reducing (CCC) and (ICP) improves operational efficiency [10]. However, average collection period (ACP) and average payment period (APP) have different results across countries.

On the basis of inheriting the research results in Vietnam and in the world, considering the specific aspects of the operation of securities companies in the field of financial services and securities, the author draws out indicators to measure the relationship between working capital, cash flow and profitability of securities companies includes:

Average collection period (ACP). In order to manage receivables, managers must know how to track receivables, through the average collection period, on the basis of which they can change trade credit policies in a timely manner.

\begin{tabular}{|l|c|}
\hline \multirow{2}{*}{ Average collection period $(\mathrm{ACP})=$} & Average receivables for the period \\
\cline { 2 - 2 } & Average revenue per day \\
\hline
\end{tabular}

In case (ACP) increases but sales and profits do not increase, the capital of the business has been stagnant at the payment stage, managers must take timely intervention measures.

Average payment period (APP). Managers must understand that the fast or slow repayment of debt to the seller will affect the cash flow, thus affecting the capital movement and the liquidity of the business. Cost of goods sold for 1 day 
- Cash Conversion Cycle (CCC): The principle of working capital management is to collect cash as quickly as possible and defer accounts payable to suppliers as long as possible, this principle is based on the concept of the cash conversion cycle. cash conversion, (CCC) is defined as the time period from payment of liabilities to receipt of cash, (CCC) calculated by the formula.

\section{Cash conversion cycle $(\mathrm{CCC})=$ \\ Average collection period (ACP) - Average payment period (APP)}

The cash conversion cycle is also a useful way to gauge a company's cash flow because it measures the length of time it has invested in working capital.

- Net cash flow for the period (NCF). Cash flow in a business period is created by the movement and combination of two cash inflows and outflows. In particular, cash inflows have the effect of supplementing the budget, which comes from revenues from customers, tenants, investors, business partners of the business... Cash outflow reduces the budget to meet payment needs during the operation of the business. Cash flow into or out of the treasury is usually divided into 3 parts: Cash flow in or out of the fund for production and business activities; Cash flow into or out of investment activities fund; Cash inflows or outflows for financing activities.

After forecasting cash flows, management aggregates the results into a hypothetical cash flow statement for the next period to determine the cash balance of the business. The closing balance is less than zero, which means that if spending is based on the opening cash and other sources of the period, the enterprise cannot pay in full and on time for expenses incurred in the period. On the contrary, the closing cash is greater than zero, showing that the enterprise can ensure the solvency in the period, and at the same time, there is a certain amount of money left over to supplement the following period.

\subsection{Research model}

(1) Objectives of quantitative research. The author tests the impact of the relationship between working capital and cash flow on the profitability of securities companies in the period 2012-2019, the results serve as a basis for accurately assessing the effects, helping securities companies have solutions to increase profitability in production and business activities.

(2) Research data. The data used by the $\mathrm{PhD}$ student is secondary data, taken from the website (Vietstock.vn), from the annual reports of securities companies and the General Statistics Office (Gso.gov.vn). The data set includes financial statements of 48 securities companies in the period 2012-2019, 238 observations, the author will exclude newly established or consolidated securities companies, which makes financial data not comparable and unjust provide sufficient information for the study.According to Bollen (1989) when analyzing the model with linear structure, the sample size is calculated according to the formula $\mathrm{n}=5^{*} 2 \mathrm{i}$ ( $\mathrm{i}$ is the observed variable in the model). According to Tabachnick and Fidell (2007) the sample size in multiple linear regression analysis is calculated according to the formula $\mathrm{n}=50+8 \mathrm{q}(\mathrm{q}$ is the number of independent variables in the model). Variables are represented in the form of array data (Panel Data) with two dimensions: the time dimension (from 2012 to 2019), the business dimension (48 securities companies).

(3)Research Methods. The author uses STATA 14 software to analyze and select a tobit model, also known as the censored regession model, the model has the form.

$$
Y_{i}^{*}=\beta_{1} \mathrm{ACP}_{\mathrm{i}}+\beta_{2} \mathrm{APP}_{\mathrm{i}}+\mathrm{i}^{*} \mathrm{NCF}+\mu_{\mathrm{i}}
$$

In which:

$$
Y_{i}=0 . \text { if } Y_{i}^{*}<=0.06
$$

$=Y_{i}^{*}$ if $Y_{i}^{*}>0.06$ (0.06 is the moderated value corresponding to higher than mean ROE in the sample) With $\square \mathrm{i} \sim \mathrm{N}(0, \square 2)$ and $\mathrm{Yi}$ is the variable representing the profitability of securities companies (ROE/ROA). The explanatory variables are average collection period, average payment period, and net cash flow dummy for the period.

- Hypotheses the expected effects of the factors on the profitability of securities companies:

\begin{tabular}{|l|l|l|l|}
\hline No. & Variable names and symbols & Calculation formula & $\begin{array}{l}\text { Expected } \\
\text { impact }\end{array}$ \\
\hline \multicolumn{2}{|l|}{ The dependent variable is ROE/ROA representing profitability variable } & \\
\hline \multicolumn{2}{|l|}{ The independent variable includes } \\
\hline
\end{tabular}




\begin{tabular}{|c|l|l|l|}
\hline 1 & $\begin{array}{l}\text { Average collection period } \\
\text { (ACP) }\end{array}$ & $\begin{array}{l}\text { Average receivables for the period/Average revenue } \\
\text { per day }\end{array}$ & + \\
\hline 2 & $\begin{array}{l}\text { Average Payment Period } \\
\text { (APP) }\end{array}$ & $\begin{array}{l}\text { Average liabilities during the period/Cost of goods } \\
\text { sold per day }\end{array}$ & - \\
\hline 3 & $\begin{array}{l}\text { Net cash flow for the } \\
\text { period (NCF) }\end{array}$ & $\begin{array}{l}\text { Dummy variable, difference Total revenue and } \\
\text { expenditure of three activities of business, } \\
\text { investment and finance, i has 2 levels, negative } \\
\text { value =1, positive value =2 }\end{array}$ & \\
\hline
\end{tabular}

Description of variables participating in the Tobit model

- summarize ROE ROA ACP APP CCC NCF

\begin{tabular}{r|rrrrr} 
Variable & Obs & Mean & Std. Dev. & Min & Max \\
\hline ROE & $\mathbf{3 7 0}$ & .0507857 &. $\mathbf{2 6 6 7 9 4 8}$ & -.8409019 & $\mathbf{4 . 6 2 7 8 0 4}$ \\
ROA & $\mathbf{3 7 0}$ & .0256387 & .0797567 & -.3485999 & .4276845 \\
ACP & $\mathbf{3 7 0}$ & $\mathbf{9 4 2 . 0 1 6 4}$ & $\mathbf{2 7 5 8 . 8 4 9}$ & $\mathbf{6 7 5}$ & $\mathbf{3 1 3 3 2 . 5}$ \\
APP & $\mathbf{3 7 0}$ & $\mathbf{5 3 5 5 . 1 3 8}$ & $\mathbf{5 3 8 2 7 . 9 8}$ & $\mathbf{6 . 7 2 1 6 8 3}$ & $\mathbf{1 0 3 0 5 5 4}$ \\
CCC & $\mathbf{3 7 0}$ & $\mathbf{- 4 4 1 3 . 1 2 1}$ & $\mathbf{5 3 8 8 7 . 0 2}$ & $\mathbf{- 1 0 3 0 5 5 1}$ & $\mathbf{2 0 4 7 8 . 4}$ \\
\hline NCF & $\mathbf{3 7 0}$ & $\mathbf{1 . 5 5 4 0 5 4}$ & .4977427 & $\mathbf{1}$ & 2
\end{tabular}

Table 3.1 List of variables in the tobit regression model

(Source: Author of statistics on STATA 14 software)

Table 3.1 for the sample statistics with 370 observations, the mean (ROE) has a mean value of 0.0507 , (ROA) has a mean value of 0.0256 , the variable (ACP) has a minimum value of 0 , high value The lowest value is 31332.5 , similarly the variable (APP) has the smallest value of 6.721683 , the highest is 1030554 .

The ROE variable around the mean concentrates most of the observations

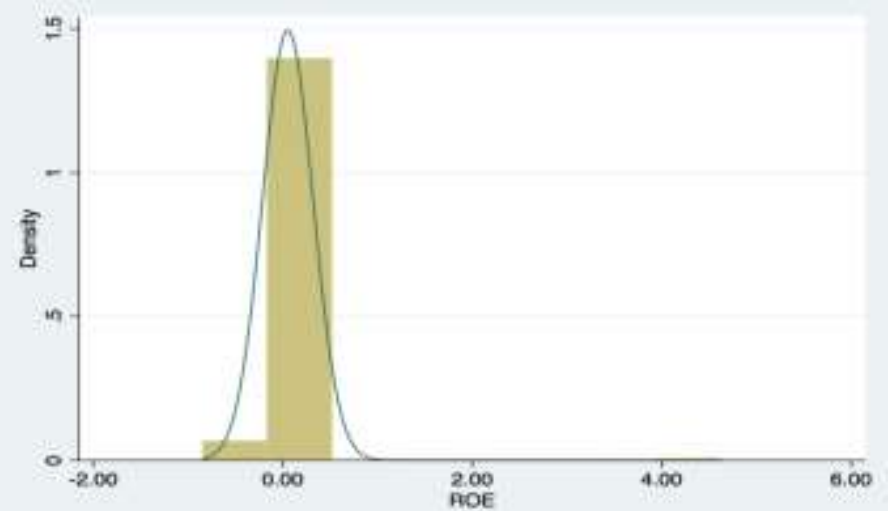

Figure 3.1 ROE variation chart of securities companies in the period 2012-2019 (Source: The author got the results from stata 14 software)

Dependent variable ROA, ROE. Profitability is the combined result of the securities company's capacity, organization, management level, operating results and final business performance in each period. Securities companies can only get profits after determining the optimal financial structure of the business and maintaining it in the course of business operations, most securities companies have not done this, when the ROA results and ROE is listed in the table below:

\begin{tabular}{|c|c|c|c|c|c}
\hline \multicolumn{7}{|c}{ Descriptive Statistics } \\
\hline YEAR & $\mathrm{N}$ & Minimum & Maximum & Mean & $\begin{array}{c}\text { Std. } \\
\text { Deviation }\end{array}$ \\
\hline 2012 & 48 & $-21.9 \%$ & $21.6 \%$ & $.491 \%$ & $6.7446 \%$ \\
\hline 2013 & 48 & $-30.5 \%$ & $42.8 \%$ & $1.385 \%$ & $9.2970 \%$ \\
\hline 2014 & 48 & $-34.9 \%$ & $16.5 \%$ & $2.216 \%$ & $8.4618 \%$ \\
\hline 2015 & 48 & $-20.9 \%$ & $27.6 \%$ & $1.969 \%$ & $6.6874 \%$ \\
\hline 2016 & 48 & $-34.4 \%$ & $25.1 \%$ & $.780 \%$ & $8.7257 \%$ \\
\hline 2017 & 48 & $-20.3 \%$ & $51.3 \%$ & $6.464 \%$ & $10.7809 \%$ \\
\hline 2018 & 48 & $-4.1 \%$ & $34.2 \%$ & $4.151 \%$ & $6.3202 \%$ \\
\hline 2019 & 48 & $-13.1 \%$ & $27.3 \%$ & $3.681 \%$ & $6.3255 \%$ \\
\hline $\begin{array}{c}\text { Valid } \mathrm{N} \\
\text { (listwise) }\end{array}$ & 48 & & & & \\
\hline
\end{tabular}

Table 3.2 ROA results of Vietnamese securities companies from 2012 to 2019

(Source: PhD student in statistics on SPSS 20 software) Observations (table 3.2) show that the average return on assets (ROA) of the sample of Vietnamese securities companies researched tends to increase, specifically over the years as follows: 2012 ROA was the 
lowest in the years. research, with an average of $0.491 \%$; In 2013 ROA increased to $1.385 \%$; In 2014 ROA increased to 2.216\%; In 2015 ROA decreased to $1.969 \%$; In 2016 ROA decreased to $0.780 \%$; In 2017 ROA increased to the highest over the years studied at $6,464 \%$, in 2018 ROA was $4,151 \%$; In 2019, the average ROA decreased to $3.681 \%$. Statistical results show that the system of securities companies in Vietnam shows that the ROA (2017-2019) of securities companies tends to increase but is low (years are less than $6.5 \%$ ) and the change is unstable (Figure 3.2).

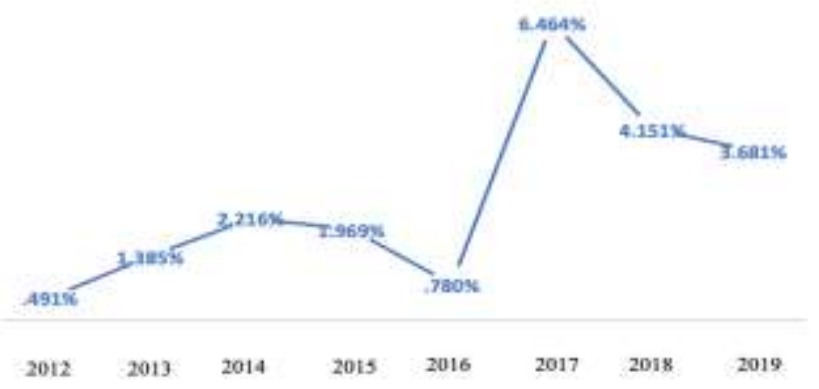

Figure 3.2 Change of ROA of Vietnamese securities companies from 2012 to 2019

(Source: The author drew the figure based on the data on excel 2010)

Especially, the difference in ROA of securities companies is quite large, there are securities companies with high positive ROA (51.3\%), but there are securities companies with very low ROA (-34.4\%).

\begin{tabular}{|c|c|c|c|c|c}
\hline \multicolumn{7}{|c}{ Descriptive Statistics } \\
\hline YEAR & $\mathrm{N}$ & Minimum & Maximum & Mean & $\begin{array}{c}\text { Std. } \\
\text { Deviation }\end{array}$ \\
\hline 2012 & 48 & $-44.5 \%$ & $22.0 \%$ & $.351 \%$ & $10.6325 \%$ \\
\hline 2013 & 48 & $-84.1 \%$ & $462.8 \%$ & $9.383 \%$ & $68.6857 \%$ \\
\hline 2014 & 48 & $-49.2 \%$ & $27.1 \%$ & $4.550 \%$ & $12.3582 \%$ \\
\hline 2015 & 48 & $-33.7 \%$ & $30.3 \%$ & $3.182 \%$ & $9.9362 \%$ \\
\hline 2016 & 48 & $-46.8 \%$ & $27.7 \%$ & $1.255 \%$ & $12.5162 \%$ \\
\hline 2017 & 48 & $-20.8 \%$ & $52.1 \%$ & $9.505 \%$ & $12.4600 \%$ \\
\hline 2018 & 48 & $-17.0 \%$ & $42.9 \%$ & $6.663 \%$ & $9.5661 \%$ \\
\hline 2019 & 48 & $-14.5 \%$ & $37.6 \%$ & $5.957 \%$ & $8.3445 \%$ \\
\hline $\begin{array}{c}\text { Valid N } \\
\text { (listwise) }\end{array}$ & 48 & & & & \\
\hline
\end{tabular}

Table 3.3 ROE results of Vietnamese securities companies from 2012 to 2019 (Source: PhD student in statistics on SPSS 20 software)

Similarly, ROE of Vietnamese securities companies is also not high, observed (table 3.3), specifically over the years as follows: 2012 ROE was the lowest in the research years, with an average of $0.351 \%$; In 2013 ROE increased to 9,383\%; In 2014 ROE increased to 4,550\%; In 2015 ROE decreased to 3,182\%; In 2016 ROE decreased to 1.255\%; In 2017 ROE increased to the highest over the years studied at 9,505\%, in 2018 ROE was 6,663\%; In 2019 the average ROE decreased to 5.957\% (Figure 3.3).

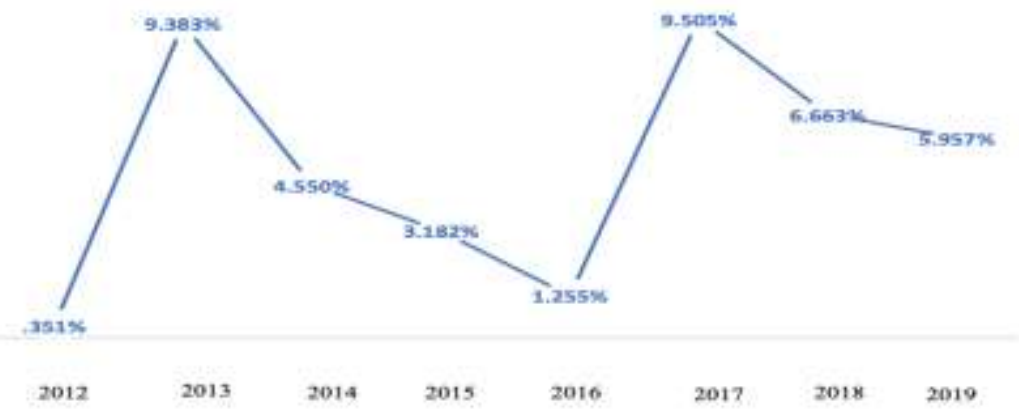

Figure 3.3 Change of ROE of Vietnamese securities companies from 2012 to 2019 (Source: The author drew the figure based on the data on excel 2010)

Thus, the results of production and business activities, profitability on assets and on equity (ROA and ROE) of securities companies during the research period (from 2012 to 2019) were relatively low. 


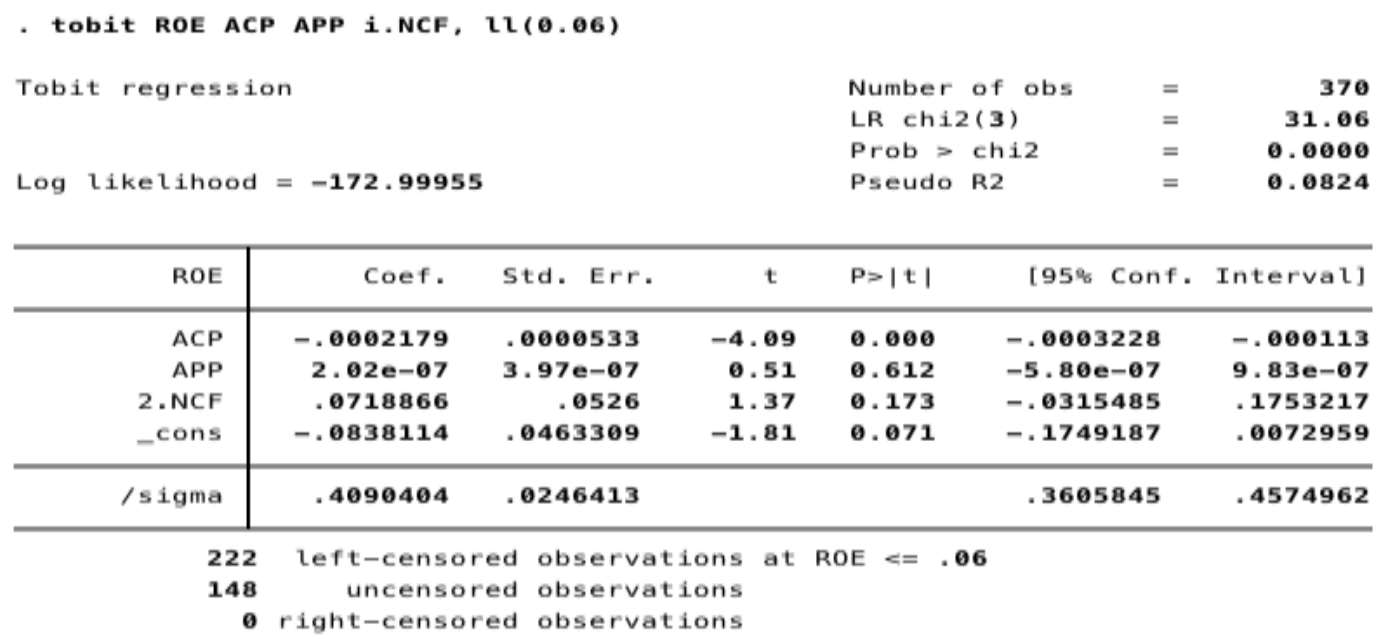

\section{Table 3.4 Regression results affecting the relationship between working capital and net cash flow on profitability ROE}

(Source: Author of statistics on STATA 14 software)

Table 3.4 regression results with dependent variable (ROE), and similar to results of regression variable (ROA)

Observing table 3.4 gives us Regression results, there are all 370 observations in the data set included in the analysis, of which there are 222 samples, 222 samples are blocked (ROE>=0.06), 148 samples are not blocked, Price LR chi2(3) with 3 degrees of freedom equal to 31.06 shows that the model fits (better) than the model without (does not contain any explanatory variables) at $1 \%$ significance level, Pseudo R2 equals 0.0824 , that is, the independent variables explain $82.4 \%$ of the variation of the dependent variable. If the variable (ACP) increases by 1 unit, it will reduce 0.0002179 in the predicted value of the variable (ROE), and the variable (APP) does not affect the dependent variable (ROE).

- The relationship between working capital and cash flow affects profitability.

+ Average collection period (ACP) has a negative effect on profitability on ROE/ROA. That is, (ACP) decreases, ROE will increase, this is consistent with the research results of Lazaridis and partners (2006), Ganesan (2007), AIShattarat and partners (2010), Vahid and partners (2012)), Afrifa and partners (2016), Osama and partners (2020), Kayani partners (2020), when the average collection period decreases, while sales and profits do not increase, capital will be Faster recovery, increasing operational efficiency. In other words, shortening the cash conversion cycle, shortening the receivables collection period will increase profitability.

+ Average pay period (APP), which is not statistically significant in the tobit model, and also tends to have a positive effect on profitability (ROE), which means that the length of time to pay the bills is extended. Debt has a more or less beneficial impact on the profitability of securities companies.

\section{Implications of solution management to improve profitability for securities companies.}

The research results show that the management of securities companies wants to increase the profitability of $\mathrm{ROE} / \mathrm{ROA}$, the best solution is to shorten the cash conversion cycle, shorten the receivable collection period. must take the following measures to limit investment in working capital:

First, change the securities company's trade credit policy towards customers, investors and partners.

Second, Reorder the list of receivables by time. Based on the cash needs of the business, the manager will apply management measures for each debt, arrange and track the length of the receivable period to take measures to settle the debt repayment when due.

Third, Determine the balance of accounts receivable. Using this method, enterprises can fully see the outstanding debt of customers who owe the business, thereby taking timely impact measures.

\section{Conclusion:}

Securities companies are an important intermediary financial institution in the modern economy, closely associated with services related to stock market operations and capital markets. However, the operating results in the period 2012-2019 are not really high, the results of return on equity (ROE) and return on assets 
(ROA) are relatively low. Securities companies need to have timely solutions to improve economic and financial profitability, with securities companies with positive cash flow, they should limit investment in working capital, shorten the cash conversion cycle, and shorten the collection period. receivables through measures: change in trade credit policy; reorder the list of receivables over time; determine the receivable balance, thereby helping the securities company to develop sustainably and satisfy investors as well as improve the quality, efficiency and safety of the stock market.

\section{Documents}

\section{Vietnamese}

1. Bui Thu Hien (2017), Working capital management in relation to business performance of pharmaceutical companies listed on Vietnam stock market, Foreign Trade University

2. Government (2019), Project No. 242/QD-TTg dated February 28, 2019 "restructuring the stock market and insurance market to 2020 and orientation to 2025.

3. Ha Quoc Thang (2019), Working capital management at enterprises under 319 Corporation, Academy of Finance

4. Nguyen Nhu Y (1998), Vietnamese Great Dictionary, Culture and Information Publishing House

5. English

6. Afrifa, G.A. and Padachi, K. (2016), Working capital level infuence on SME profitability, Journal of small business and enterprise development, Vol.23 No.1, pp. 44-63, ISSN: 1462-6004, https://doi.org/10.1108/ https://doi.org/10.1108/JSBED-01-2014-0014

7. AlShattarat, W.K., Nobanee, H., Haddad, A.E., Alhaijjar, M.(2010), Working capital Management, Operating Cash Flow and Corporate Performance, International Journal of Strategic Management, 10(1), PP.84-88.

8. Ganesan, V.(2007), An analysis of working capital manaêmnt efficiency in telecommunication equipment industry, Rivier academic journal, Volue 3, No.2

9. Kayani, UN. And De Silva, TA. and Gan, C.(2020), Working capital Management and Firm Performance Relationship: An Empirical Investigation of Australasian Firms, Review of Pacific Basin Financial Markets and Policies Vol.23,No.03, https://doi.org/10.1142/S0219091520500265

10. Lazaridis, I., Tryfonidis, D.(2006), Relationship between working capital management and profitability of listed companies in the Athens stock exchange, Journal of Financial Management \& Analysis; Jan-Jun 2006; 19,1; Abi/inform collection pg.26

11. Osama, ELA. and Gazzar, H.Al. (2020), Working capital and financial performance in MENA region, Journal of Humanities and Applied Social Sciences, ISSN: 2632-279X, https://doi.org/10.1108/JHASS02-2020-0036

12. Vahid, TK., Elham, G., Khosroshahi M, Mohammadreze, E. (2012), Working capital management and corporate performance: Evidence from Iranian Companies, Procedia - Social and Behavioral Sciences Volume 62, 24 October 2012, Pagess 1313-1318, https://doi.org/10.1016/j.sbspro.2012.09.225 